\title{
Effect of lignin linkages with other plant cell wall components on in vitro and in vivo neutral detergent fiber digestibility and rate of digestion of grass forages
}

\author{
E. Raffrenato, ${ }^{\ddagger} †$ R. Fievisohn, $\ddagger$ K. W. Cotanch, $\ddagger$ R. J. Grant, $\ddagger$ L. E. Chase,${ }^{*}$ and M. E. Van Amburgh* \\ ${ }^{*}$ Department of Animal Science, Cornell University, Ithaca, NY 14853 \\ tDepartment of Animal Sciences, Stellenbosch University, Stellenbosch, South Africa 7600 \\ ¥William H. Miner Agricultural Research Institute, Chazy, NY 12921
}

\begin{abstract}
The objective of this study was to correlate in vitro and in vivo neutral detergent fiber (NDF) digestibility (NDFD) with the chemical composition of forages and specific chemical linkages, primarily ester- and etherlinked para-coumaric $(p \mathrm{CA})$ and ferulic acids (FA) in forages fed to dairy cattle. The content of acid detergent lignin (ADL) and its relationship with NDF does not fully explain the observed variability in NDFD. The ferulic and $p$-coumaric acid linkages between ADL and cell wall polysaccharides, rather than the amount of ADL, might be a better predictor of NDFD. Twentythree forages, including conventional and brown midrib corn silages and grasses at various stages of maturity were incubated in vitro for measurement of 24-h and 96-h NDFD. Undigested and digested residues were analyzed for NDF, acid detergent fiber (ADF), ADL, and Klason lignin (KL); ester- and ether-linked $p \mathrm{CA}$ and FA were determined in these fractions. To determine whether in vitro observations of ester- and ether-linked $p \mathrm{CA}$ and FA and digestibility were similar to in vivo observations, 3 corn silages selected for digestibility were fed to 6 ruminally fistulated cows for $3 \mathrm{wk}$ in 3 iso-NDF diets. Intact samples and NDF and ADF residues of diet, rumen, and feces were analyzed for ester- and ether-linked $p \mathrm{CA}$ and FA. From the in vitro study, the phenolic acid content (total $p \mathrm{CA}$ and FA) was highest for corn silages, and overall the content of ester- and ether-linked $p \mathrm{CA}$ and FA in both NDF and ADF residues were correlated with NDF digestibility parameters, reflecting the competitive effect of these linkages on digestibility. Also, Klason lignin and ADL were negatively correlated with ether-linked ferulic acid on an NDF basis. Overall, esterified FA and esterified $p \mathrm{CA}$ were negatively correlated with all of the measured
\end{abstract}

\footnotetext{
Received November 27, 2016.

Accepted June 5, 2017.

${ }^{1}$ Corresponding author: mev1@cornell.edu
}

fiber fractions on both a dry matter and an NDF basis. The lignin content of the plant residues and chemical linkages explained most of the variation in both rate and extent of NDF digestion but not uniformly among forages, ranging from 56 to $99 \%$. The results from the in vivo study were similar to the in vitro data, demonstrating the highest total-tract aNDF digestibility (70\%; NDF analysis conducted with $\alpha$-amylase and sodium sulfite) for cows fed the corn silage with the lowest ester- and ether-linked $p \mathrm{CA}$ content in the NDF fraction. In this study, digestibility of forage fiber was influenced by the linkages among lignin and the carbohydrate moieties, which vary by hybrid and species and most likely vary by the agronomic conditions under which the plant was grown.

Key words: phenolic acids, digestibility, lignin, neutral detergent fiber

\section{INTRODUCTION}

Forages are the foundation of all ruminant diets and forage digestibility is of significant importance for DMI and optimum rumen function including energy and microbial yield. Chemical and physical interactions between lignin and the carbohydrate moieties of plant cell walls affect the rate and extent of NDF digestion (Cherney et al., 1991). Data generated in our laboratory indicated that corn silages can have almost identical chemical composition (NDF and lignin) but vary 2-fold in NDF digestibility (NDFD; Van Amburgh et al., 2015). Thus, the content of lignin is not directly responsible for digestibility of corn silage; more likely, the degree of cross-linking of phenolics within the cell wall carbohydrate directly influences digestibility. Effects of specific linkages among lignin and cell wall carbohydrates were demonstrated by Grabber et al. (2009), who used a biomimetic model to show that ferulate cross-linking was more important than lignin content in determining the rate and extent of digestion of hemicellulose. 
Lignin is resistant to bacterial and fungal degradation in the rumen, and small amounts of lignin can be solubilized but not digested over time depending on linkage type. Its association with other cell wall matrix components greatly influences properties of digestion, including the enzymatic degradation of structural polysaccharides (Akin and Benner, 1988). Reductions in degradability are partly related to the increased lignin content of cell walls; however, variations in 3-dimensional structure and composition of lignin and its hydrophobicity, encrustation, and cross-linking to other matrix components have also been implicated (Chesson, 1993; Jung and Deetz, 1993). Even when plant selection is targeted at specific lignin properties or lignin-matrix interactions, compensatory or associative changes in other cell wall characteristics often occur, making it difficult to identify underlying mechanisms controlling cell wall degradability (Grabber, 2005). Plants might, for example, respond to lower lignin content by increasing the amount of cross-linking, yielding no net change in digestibility, thus lignin content as a marker of digestibility might be misleading to a nutritionist (Chabannes et al., 2001).

In grasses, hydroxycinnamic acids; namely, $p$-coumaric acid ( $\boldsymbol{p} \mathbf{C A})$ and ferulic acid (FA), are ester- or ether-linked to cell wall polymers. As result of those coupling reactions, arabinoxylans become extensively cross-linked by ferulate dimerization and incorporation of ferulate monomers and dimers into lignin. Ferulates are present as esters of arabinose units on xylans, and many of the ferulate molecules become involved in cross-links between arabinoxylans and by formation of diferulate bridges or as nucleation sites for lignin deposition (Hatfield et al., 1999). Both diferulate crosslinking of lignin to arabinoxylans and cross-linking of lignin to arabinoxylans have been shown to reduce maize cell wall degradability (Grabber et al., 1998a). Jung and Casler (2006) demonstrated a drastic increase in substitution of arabinose with ferulates (0 to 45\%), as xylans became less substituted with arabinose units during development of the maize internode.

Etherified ferulic acid, a measure of cross-linking between lignin and arabinoxylans, has a negative effect on cell wall digestibility (Casler and Jung, 1999; Lam et al., 2003), whereas esterified ferulic acid exhibits inconsistent effects on digestibility (Jung and Casler, 1990, 1991). Further, Casler and Jung (2006) reported negative effects of esterified ferulic acid on in vitro 24-h NDFD of smooth bromegrass and reed canarygrass, but the relationship became positive when digestibility was measured at $96 \mathrm{~h}$. If the majority of $p \mathrm{CA}$ is esterified to lignin and if $p \mathrm{CA}$ ethers are only linked to lignin (Lam et al., 1992a,b, 2001; Jung and Deetz, 1993), it is probable that these components do not di- rectly affect digestibility. Negative correlations between lignin and ester and ether $p \mathrm{CA}$ and positive correlations with etherified ferulate and cell wall digestibility have been reported in meadow hay (Rodrigues et al., 2007). Further, negative correlations between etherified FA and cell wall polysaccharide degradability in young maize internodes, but not in mature plants, have been reported by Jung et al. (1998).

A few studies have compared in vitro and in vivo digestion data with the chemical linkages associated with rate and extent of digestion. Jung et al. (1991) compared recoveries of esterified phenolic acids after in vitro fermentation with previous in vivo data (Jung et al., 1983), and they obtained greater recoveries with increasing concentrations of esterified phenolic acids in both cases. Further, Jung et al. (1991) assessed the changes that phenolic monomers of forages undergo during digestion, rather than their direct effect on in vivo digestibility. The $p \mathrm{CA}$ and $\mathrm{FA}$ in $\mathrm{ADF}$ have rarely been estimated and because ADF isolates cellulose and lignin, both phenolic acids should be detectable. However, complete recovery of those phenolic acids could be difficult because the ADF analysis might solubilize some of the phenolics because it dissolves a portion of the lignin contained in the Klason lignin (Hatfield and Fukushima, 2005).

Overall, there is a need to integrate observations relative to phenolic acids and nutritive value, focusing on phenotypic correlations associated with rate and extent of digestibility of forages. The objective of this study was to correlate in vitro and in vivo NDFD with the chemical composition of forages and specific chemical linkages, primarily ester- and ether-linked $p \mathrm{CA}$ and FA, in forages fed to dairy cattle and investigate whether the presence of measurable ester and ether linkages affected rate and extent of NDF digestibility. Further, we wanted to investigate the relationship in 3 corn silage hybrids selected for digestibility and the correlation with ester and ether linkages and in vivo digestibility. The hypothesis was that the extent and rate of NDF digestibility of forages commonly fed to dairy cattle are affected by these ester and ether linkages, which vary by maturity, varietal genetics, and agronomic factors.

\section{MATERIALS AND METHODS}

\section{In Vitro Study}

Twenty-three forages, including conventional and brown midrib (bmr) corn silages and immature and mature grasses, were dried at $40^{\circ} \mathrm{C}$ for $48 \mathrm{~h}$ in a forced-air oven, and ground to pass through a 1-mm screen using a Wiley mill (Thomas Scientific, Swedesboro, NJ). The forages were selected based on previous analyses that 
demonstrated wide differences in digestibility among the samples and it was assumed that large differences in digestibility would allow for the greatest chance of detecting the linkages. The forages were samples from previous experiments; however, little information was available to describe the hybrid or genetics other than conventional or bmr for the corn silages. After processing, samples were stored in screw-topped plastic containers at room temperature. All forages for the in vitro and phenolic acid analysis were analyzed for NDF and the forages for the in vivo study were analyzed for aNDFom (NDF analysis conducted with $\alpha$-amylase and sodium sulfite and ash correction; Mertens, 2002) for formulation. The use of sodium sulfite was omitted in the NDF procedure to reduce the potential of lignin bonds being cleaved between hemicellulose and lignin (Robertson and Van Soest, 1981) and biasing the phenolic acid recoveries; however, amylase was used. Further, all forages were analyzed for ADF (Van Soest, 1963), ADL (Raffrenato and Van Amburgh, 2011), and Klason lignin (KL; Theander et al., 1995).

Forages were incubated in vitro with ruminal fluid for 0-, 6-, 12-, 24-, 48-, 72-, 96-, 120-, and 240-h NDFD (Goering and Van Soest, 1970) in 125-mL Erlenmeyer flasks under constant $\mathrm{CO}_{2}$. Ruminal fluid was taken from 2 lactating cattle fed a diet to support approximately $43 \mathrm{~kg}$ of ME-allowable milk (approximately $55 \%$ forage, $16.7 \% \mathrm{CP}, 32 \% \mathrm{NDF}$, and $27 \%$ starch), placed in a warmed thermos, and transported to the laboratory within $30 \mathrm{~min}$ of harvesting. The ruminal fluid was strained through 4 layers of cheesecloth and glass wool and immediately pipetted into the Erlenmeyer flasks. All samples were filtered through a glass microfiber filter with porosity of $1.5 \mu \mathrm{m}$ (934-AH, Whatman Ltd./ GE Healthcare, Maidstone, UK), inserted in 50-mL Pyrex Gooch crucibles (Raffrenato and Van Amburgh, 2011). The 24- and 96-h NDFD residues were used to evaluate the effect of phenolic acid linkages on rate and extent of digestion. These time points were chosen because they represent the time points in the fermentation where the digestion rates are in the linear portion of both the fast pool and slow pool of NDF digestion, and the linkages should be detectable at each endpoint (Raffrenato and Van Amburgh, 2010). Further, rates of NDF digestion were computed using a first-order decay model according to the following equation:

$$
\mathrm{NDF}_{(\mathrm{t})}=\operatorname{pdNDF}_{(0)} \times \mathrm{e}^{-\mathrm{k}_{\mathrm{d}} \mathrm{NDF}(\mathrm{t}-\mathrm{LNDF})}+\mathrm{iNDF}
$$

where $\operatorname{pdNDF}_{(0)}$ is the size at time 0 of the potentially digestible NDF; $k_{d}$ is the fractional NDF rate of digestion; L is the lag, and iNDF is the indigestible NDF. Simultaneous estimations of the parameters pdNDF, $\mathrm{k}_{\mathrm{d} \text { NDF }}$, iNDF, and L were initially obtained using PROC NLIN of SAS (version 9.3; SAS Institute, Inc., Cary, NC) and the Marquardt algorithm. The ADL analyses were conducted on ADF residues (Van Soest, 1963).

Before conducting the study, the method for $p \mathrm{CA}$ or FA extraction was evaluated. The extraction method was a modification of Iiyama et al. (1990) and Jung and Shalita-Jones (1990); where extraction with $4 \mathrm{~N}$ $\mathrm{NaOH}$ was performed in a microwave oven instead of the $170^{\circ} \mathrm{C}$ oven. The microwave (Mars 5 Xpress, CEM Corp., Matthews, NC) was set at 1,600 W and the extraction was conducted using a 5-min ramp to $180^{\circ} \mathrm{C}$ in $\mathrm{CEM} 55-\mathrm{mL}$ TFM (Teflon-lined) microwave digestion tubes (CEM Corp.). Extracted samples were stored at $-20^{\circ} \mathrm{C}$. Phenolic acid separation was performed on a Waters Spherisorb ODS-2 $(4.6 \times 250 \mathrm{~mm}$, $5 \mu \mathrm{m}$; Waters, Milford, MA) column with a Supelco Pelliguard LC-18 (2 cm, Supelco Inc., Bellefonte, PA) guard column. Temperature of the column was set at $50^{\circ} \mathrm{C}$. Samples $(20 \mu \mathrm{m})$ were eluted with a mobile phase consisting of a solution of $97.7 \%$ water, $2 \%$ butanol, and $0.3 \%$ glacial acetic acid (solution A) and methanol (solution B) as follows: isocratic elution 100\% A, 0-20 min; linear gradient from $100 \% \mathrm{~A}$ to $80 \% \mathrm{~A} / 20 \% \mathrm{~B}$, 20-27 min; linear gradient from $80 \% \mathrm{~A} / 20 \%$ B to $100 \%$ A, 28-31 min. Flow rate was $1.8 \mathrm{~mL} / \mathrm{min}$ and the injection volume was $20 \mu \mathrm{L}$. The monitoring wavelength was $320 \mathrm{~nm}$ with a $4-\mathrm{nm}$ bandwidth. The $p \mathrm{CA}$ and FA were detected at $320 \mathrm{~nm}$, with a $4-\mathrm{nm}$ bandwidth, and quantified using the external calibration method.

Three recovery tests were conducted to validate the modification. In the first recovery test, 2 solutions were made containing FA or $p \mathrm{CA}$. The FA solution contained $26.19 \mathrm{mg}$ of FA (99\% purity) solubilized in $500 \mathrm{~mL}$ of $4 \mathrm{~N} \mathrm{NaOH}$ solution for a final concentration of 51.86 $\mathrm{mg} / \mathrm{L}$. The $p \mathrm{CA}$ solution contained $26.42 \mathrm{mg}$ of $p \mathrm{CA}$ (98\% purity) solubilized in $500 \mathrm{~mL}$ of $4 \mathrm{~N} \mathrm{NaOH}$ solution for a final concentration of $51.78 \mathrm{mg} / \mathrm{L}$. Working standards were prepared in $500 \mathrm{~mL}$ of $50 \%$ ( $\mathrm{vol} / \mathrm{vol}$ ) aqueous solution of methanol. The FA working standard contained $101.82 \mathrm{mg}$ of $99 \%$ pure $\mathrm{FA}$ in $500 \mathrm{~mL}$ with a final concentration of $201.60 \mathrm{mg} / \mathrm{L}$. The $p \mathrm{CA}$ working standard contained $102.39 \mathrm{mg}$ of $p \mathrm{CA}$ that was $98 \%$ pure in $500 \mathrm{~mL}$ for a final concentration of 200.68 $\mathrm{mg} / \mathrm{L}$. Similar standards were used in all 3 recovery evaluations. The first recovery test used the microwave technique, where solutions were microwaved alone or the solutions were used to spike a sample of corn bran with either $p \mathrm{CA}$ or $\mathrm{FA}$ for evaluation of recovery. Corn bran was chosen as a carrier because it does not contain high amounts of $p \mathrm{CA}$ or FA. The second recovery test evaluated the recovery of $\mathrm{FA}$ and $p \mathrm{CA}$ with and without the use of the microwave to heat the sample. Again, the FA and pCA solutions and standards were 
prepared in the same manner as those used in the first test. A third recovery test was performed to evaluate the necessity of heating during the procedure. This was done because the solutions were applied to the corn bran, and extraction should be relatively simple; thus, this test evaluated the effect of heating in the microwave or not using any heat for extraction on stability of the FA and $p \mathrm{CA}$.

Preliminary analyses failed to detect phenolic acids in $\mathrm{ADL}$; therefore, $\mathrm{ADL}$ residues were not analyzed for $p \mathrm{CA}$ or FA for the study. Intact samples, NDF, ADF, and $\mathrm{KL}$ residues were analyzed for ester- and etherlinked $p$ CA (Es- $\boldsymbol{p} \mathbf{C A}, \mathbf{E t}-\boldsymbol{p} \mathbf{C A})$ and ester- and etherlinked FA (Es-FA, Et-FA) using modified procedures by Iiyama et al. (1990) and Jung and Shalita-Jones (1990). Extraction of $p \mathrm{CA}$ and FA was by using $2 N$ and $4 \mathrm{~N} \mathrm{NaOH}$ using a microwave heating method as previously described.

\section{In Vivo Study}

To determine if the observations from the in vitro study could be replicated through in vivo digestibility measurements, a parallel study was conducted using lactating dairy cattle fed 3 of the corn silage hybrids that were used in the in vitro study. Hybrids were chosen based on expected differences in in vitro NDF digestibility. Conventional low-digestibility (CLD) and highdigestibility (CHD) corn silages and a bmr corn silage (BMR) were used in the in vivo study (Chase, 2010). The inclusion of each of the corn silages in the respective TMR resulted in 46.1, 47.1, and 56.5\% 24-h NDFD (\% of $\mathrm{NDF}$ ) for CLD, CHD, and BMR, respectively (Table 1). After calving, the cattle went on a common fresh cow diet for approximately $10 \mathrm{~d}$. Cattle were then assigned to 1 of 3 treatments, transitioned onto the treatment diets, and the study was conducted for 10 weeks (Chase, 2010). Six ruminally fistulated multiparous cows were housed in tiestalls and were sampled for in vivo digestibility measurements at approximately 60 DIM. The treatments were assigned to cows in a completely randomized design. Diets were formulated to be iso-NDF and fed as TMR to $10 \%$ refusal. The diets contained 35.8, 37.8, and $35.4 \% \mathrm{NDF}$ and were $59 \%$ corn silage, $5.5 \%$ wheat straw, and $35.5 \%$ concentrate for the CLD, CHD, and BMR diets, respectively (Table 2). Samples of TMR, feces, urine, plasma, and rumen were taken every $3 \mathrm{~h}$ for $3 \mathrm{~d}$. The cannula plug was removed and the rumen contents closest to the plug were discarded. A $100-\mathrm{mL}$ plastic beaker was used to transfer $500 \mathrm{~mL}$ of rumen contents into a 1-L container, and samples were taken from the rumen in various places below and within the rumen mat. Further, urine was sampled by manual stimulation of the cow's escutcheon
Table 1. Chemical composition (\% of DM unless otherwise noted) of the corn silages used in the feeding and in vivo study

\begin{tabular}{lccc}
\hline & \multicolumn{3}{c}{ Corn silage $^{1}$} \\
\cline { 2 - 4 } Item & CLD & CHD & BMR \\
\hline DM (\%) & 36.3 & 32.9 & 32.9 \\
CP & 7.8 & 8.3 & 8.4 \\
ADF & 23.2 & 24.8 & 22.2 \\
NDF & 38.3 & 41.3 & 38.6 \\
Starch & 39.0 & 33.6 & 36.5 \\
ADL & 2.35 & 2.28 & 2.04 \\
Ash & 3.74 & 4.12 & 4.05 \\
pH & 3.86 & 3.86 & 3.82 \\
24-h NDFD & 46.1 & 47.1 & 56.5 \\
\hline
\end{tabular}

${ }^{1} \mathrm{CLD}=$ conventional corn silage selected for comparably lower NDF digestibility (NDFD); CHD = conventional corn silage hybrid selected for higher NDFD; BMR = brown midrib corn silage selected for higher NDFD.

and vulva and a 50- to $100-\mathrm{mL}$ sample was obtained. Plasma was sampled via the coccygeal vein into $10-\mathrm{mL}$ Vacutainer tubes (Becton Dickinson, Franklin Lakes, NJ). Fecal grab samples (approximately 600-1,000 g) were taken and composited over the 24 -h period for 3 $\mathrm{d}$ and then subsampled, mixed, dried in a $39^{\circ} \mathrm{C}$ forced air oven, and ground and stored in bags until analyzed. Acid insoluble ash was used to estimate fecal excretion and total-tract DM digestibility (TTD; Van Keulen and Young, 1977). Creatinine in urine was used to estimate total daily urine excretion (Chen et al., 1992). Phenolic acids in forages, TMR, rumen, and feces samples were analyzed using the procedures described above. Phenolic acids in urine and plasma were analyzed using the procedure by Zhao et al. (2003).

\section{Statistical Analyses}

To determine the amount of variation in 24-h and 96-h NDFD and $k_{d}$ explained by the effect of lignin linkages and phenolic acids, a multiple regression with stepwise selection was run within each forage group using the independent variables of lignin type (ADL or KL) and the difference between them on an NDF basis. Pearson correlation coefficients were determined among selected variables. Similarly, another multiple regression with stepwise selection was run within each forage group using phenolic acids with their specific linkages to establish correlations among phenolic acids and digestibility parameters. The collinearity between explanatory variables was assessed with variance inflation factors (VIF) and tolerance values. Only variables with VIF $<2.5$ and tolerance $>0.40$ were allowed in the models to control for collinearity (Neter et al., 1996). Significance for the associative effects was declared at $P$ $<0.10$ and specific $P$-values are stated. For the in vivo study, differences among treatment means of digestibil- 
Table 2. Ingredients and chemical composition (\% of DM unless otherwise noted) of experimental diets fed in the in vivo study and the DMI and total-tract digestibility (TTD) of the experimental diets fed to lactating cattle in the in vivo study

\begin{tabular}{|c|c|c|c|}
\hline \multirow[b]{2}{*}{ Item } & \multicolumn{3}{|c|}{ Corn silage $^{1}$} \\
\hline & CLD & CHD & BMR \\
\hline \multicolumn{4}{|l|}{ Ingredient } \\
\hline CLD & 59.25 & - & - \\
\hline CHD & - & 59.25 & - \\
\hline BMR & - & - & 59.25 \\
\hline Wheat straw & 5.55 & 5.55 & 5.55 \\
\hline Soybean hulls & 5.55 & 5.55 & 5.55 \\
\hline Molasses & 1.38 & 1.38 & 1.38 \\
\hline Soybean meal & 10.18 & 10.18 & 10.18 \\
\hline SoyPlus $^{2}$ & 6.48 & 6.48 & 6.48 \\
\hline Blood meal & 0.92 & 0.92 & 0.92 \\
\hline Animal-vegetable fat & 0.92 & 0.92 & 0.92 \\
\hline Mepron $^{3}$ & 0.07 & 0.07 & 0.07 \\
\hline Sodium bicarbonate & 1.11 & 1.11 & 1.11 \\
\hline Urea & 0.18 & 0.18 & 0.18 \\
\hline Mineral-vitamin $\operatorname{mix}^{4}$ & 2.85 & 2.85 & 2.85 \\
\hline \multicolumn{4}{|l|}{ Composition } \\
\hline $\mathrm{DM}(\%)$ & 42.3 & 44.2 & 46.6 \\
\hline $\mathrm{CP}$ & 15.0 & 14.8 & 15.8 \\
\hline RUP & 7.21 & 7.33 & 7.67 \\
\hline $\mathrm{ADF}$ & 21.3 & 22.9 & 20.6 \\
\hline aNDFom $^{5}$ & 35.8 & 37.8 & 35.4 \\
\hline Starch & 25.8 & 24.6 & 25.4 \\
\hline ADL & 2.21 & 2.46 & 1.97 \\
\hline Ash & 8.02 & 7.80 & 8.53 \\
\hline DMI $(\mathrm{kg} / \mathrm{d})$ & $25.33^{\mathrm{b}}$ & $26.53^{\mathrm{b}}$ & $26.91^{\mathrm{b}}$ \\
\hline TTD $(\%)$ & $63.32^{\mathrm{c}}$ & $66.62^{\mathrm{b}}$ & $70.23^{\mathrm{a}}$ \\
\hline
\end{tabular}

${ }^{\mathrm{a}-\mathrm{c}}$ Values within rows with different superscripts are significantly different $(P<0.05)$.

${ }^{1} \mathrm{CLD}=$ conventional corn silage selected for comparably lower NDF digestibility (NDFD); CHD = conventional corn silage hybrid selected for higher NDFD; BMR = brown midrib corn silage selected for higher NDFD.

${ }^{2}$ Dairy Nutrition Plus (Ralston, IA).

${ }^{3}$ Evonik Nutrition \& Care GmbH (Hanau, Germany).

${ }^{4}$ Calcium carbonate $=1.18 \%$; magnesium oxide $=0.18 \%$; salt-white $=$ $0.27 \%$; sodium bicarbonate $=1.1 \%$; Dynamate (The Mosaic Company, Plymouth, $\mathrm{MN})=0.45 \%$; potassium carbonate $=0.27 \%$ trace mineral mineral-vitamin premix $=0.27 \%$ (composed of zinc $=16,000 \mathrm{mg} /$ $\mathrm{kg}$; copper $=2,200 \mathrm{mg} / \mathrm{kg}$; manganese $=12,000 \mathrm{mg} / \mathrm{kg}$; iron $=0$; cobalt $=35 \mathrm{mg} / \mathrm{kg}$; iodine $=160 \mathrm{mg} / \mathrm{kg} ;$ vitamin $\mathrm{A}=1,400,000 \mathrm{IU}$; vitamin $\mathrm{D}=45,000 \mathrm{IU}$; vitamin $\mathrm{E}=10,000 \mathrm{IU}$ ).

${ }^{5}$ aNDFom $=$ NDF analysis with $\alpha$-amylase, sodium sulfite, and ash corrected for soil contamination.

ity and the phenolic acid linkages were detected using the Tukey procedure (Neter et al., 1985). Significance was declared at $P<0.05$ unless otherwise stated. All statistical analyses were conducted using SAS (version 9.1.3, 2008; SAS Institute Inc.).

\section{RESULTS AND DISCUSSION}

\section{Method Recovery Study}

In the first evaluation, recovery of the known phenolic acid standard solution after microwave digestion was $98 \%$ for FA and $104 \%$ for $p$ CA. For the spiked corn bran sample, the recovery was $99 \%$ for FA and $105 \%$ for $p \mathrm{CA}$. This demonstrated full digestion and recovery of the phenolic acids with the microwave digestion process.

In the second evaluation, there was complete recovery of $p \mathrm{CA}$ without microwave digestion and $99 \%$ recovery with digestion. For FA, there was a loss of approximately $5 \%$ without the microwave and $9 \%$ after extraction through use of the microwave. Although the phenolic acids were not bound to a substrate, the primary concern for the method was destruction of the acids in the microwave procedure; the results demonstrated that the microwave method did not destroy them. Overall, compared with previously published data (Iiyama et al., 1990; Jung and Shalita-Jones, 1990) the microwave method used in this experiment appeared to provide acceptable recoveries for the evaluation of $p \mathrm{CA}$ and $\mathrm{FA}$ esters and ethers. The data on recoveries from Iiyama et al. (1990) and Jung and Shalita-Jones (1990) indicated recovery between 58 and $60 \%$ of phenolic acids and used a multiplier to adjust for the total content.

\section{In Vitro Study}

The chemical composition, in vitro NDFD at $24 \mathrm{~h}$ and $96 \mathrm{~h}$, and cell wall phenolic acid contents (FA and $p \mathrm{CA}$ fractions) of Es- $p \mathrm{CA}, \mathrm{Et}-p \mathrm{CA}, \mathrm{Es}-\mathrm{FA}$, and Et-FA of the forages are given in Tables $3,4,5$, and 6 for the respective forage groups. The range in digestibility and chemical composition of the forages studied in this experiment were important to evaluate the effect of linkages. Consistent with literature values, the bmr corn silages were lower in NDF, ADF, and lignin, whereas 24-h NDFD was approximately $35 \%$ greater than that of the conventional corn silages (Oba and Allen, 2003; Tables 3 and 4). The range in 24-h NDFD for the mature grasses was 22.3 to $62.6 \%$, and the range for the immature grasses was 63 to $70 \%$, making the immature grasses less variable. There were varietal differences among the forages within species and unfortunately, these differences remain unknown as these forages were used in previous experiments where variety was not of interest and not recorded. It is likely that agronomic conditions such as light, temperature, and water affected the digestibility of these forages more so than variety (Akin and Chesson, 1989; Coors and Lauer, 2001; Hu et al., 2009) and again in this experiment, the information was unknown but of great interest.

The phenolic acid content was higher for whole-plant corn silages $(P<0.05)$ for Es- $p$ CA, Et- $p$ CA, Es-FA, and Et-FA (Tables 3, 4, 5, and 6). The higher concentration of $p \mathrm{CA}$ for the corn silage has been observed before and is explained by the observation that $\mathrm{C} 4$ plants have 
Table 3. Chemical composition of the conventional corn silages $(\mathrm{n}=$ 8) analyzed in the in vitro portion of the study

\begin{tabular}{lrrrc}
\hline Item $^{1}$ & Mean & SD & Minimum & Maximum \\
\hline NDF (\% of DM) & 39.61 & 5.50 & 32.11 & 46.72 \\
ADF (\% of DM) & 25.42 & 3.30 & 19.60 & 30.05 \\
KL (\% of NDF) & 18.73 & 1.95 & 16.40 & 21.86 \\
ADL (\% of NDF) & 7.17 & 1.28 & 5.51 & 9.78 \\
ivNDFD24 (\% of NDF) & 44.90 & 5.30 & 38.01 & 53.81 \\
ivNDFD96 (\% of NDF) & 67.60 & 4.40 & 62.80 & 74.90 \\
Es- $p$ CA (mg/g of DM) & 9.13 & 0.87 & 7.93 & 10.50 \\
Es- $p$ CA (mg/g of NDF) & 16.52 & 1.46 & 14.21 & 19.01 \\
Et- $p$ CA (mg/g of DM) & 0.83 & 0.72 & 0.08 & 2.21 \\
Et- $p$ CA (mg/g of NDF) & 2.35 & 0.89 & 0.79 & 3.63 \\
Es-FA (mg/g of DM) & 4.02 & 0.34 & 3.48 & 4.39 \\
Es-FA (mg/g of NDF) & 7.95 & 1.25 & 6.31 & 9.46 \\
Et-FA (mg/g of DM) & 1.65 & 0.68 & 0.76 & 2.34 \\
Et-FA (mg/g of NDF) & 3.80 & 1.11 & 2.21 & 5.62 \\
TKL Kl
\end{tabular}

${ }^{1} \mathrm{KL}=$ Klason lignin; ivNDFD24 = in vitro NDF digestibility at $24 \mathrm{~h}$; ivNDFD96 $=$ in vitro NDF digestibility at $96 \mathrm{~h}$; Es- $p$ CA $=$ esterified para-coumaric acid; Et- $p \mathrm{CA}=$ etherified para-coumaric acid; Es-FA = esterified ferulic acid; Et-FA = etherified ferulic acid.

higher $p \mathrm{CA}$ content than do C3 grasses (Cherney et al., 1989). In particular, although conventional corn silages contained higher levels of both $p \mathrm{CA}$ linkages, the FA content was greater in bmr corn silage on a NDF basis but lower on a DM basis $(P<0.05)$. Based on the data of Grabber et al. (2009), the greater FA content of the bmr silage should indicate lower potential NDF digestibility. However, the bmr mutants are known to have lower lignin values and greater esterified FA linkages to arabinoxylans instead of lignin, which appears to provide less structural integrity (Marita et al., 2003), consistent with higher digestibility.

The greater content of both Es-FA and Et-FA for bmr corn silages compared with conventional hybrids was unexpected, primarily because cross-linking of lig-

Table 4. Chemical composition of the brown midrib (bmr) corn silages $(\mathrm{n}=11)$ analyzed in the in vitro portion of the study

\begin{tabular}{lrrrr}
\hline Item $^{1}$ & Mean & SD & Minimum & Maximum \\
\hline NDF (\% of DM) & 35.57 & 3.10 & 30.90 & 41.11 \\
ADF (\% of DM) & 22.32 & 2.53 & 19.21 & 26.91 \\
KL (\% of NDF) & 16.00 & 1.86 & 13.87 & 20.07 \\
ADL (\% of NDF) & 5.37 & 6.90 & 4.42 & 6.70 \\
ivNDFD24 (\% of NDF) & 61.10 & 4.93 & 50.00 & 60.62 \\
ivNDFD96 (\% of NDF) & 80.31 & 4.20 & 71.02 & 84.91 \\
Es- $p$ CA (mg/g of DM) & 4.68 & 0.60 & 3.88 & 5.44 \\
Es- $p$ CA (mg/g of NDF) & 12.25 & 1.75 & 9.92 & 15.53 \\
Et- $p$ CA (mg/g of DM) & 0.49 & 0.22 & 0.10 & 0.87 \\
Et- $p$ CA (mg/g of NDF) & 1.41 & 0.68 & 0.31 & 2.73 \\
Es-FA (mg/g of DM) & 3.52 & 0.23 & 3.13 & 3.91 \\
Es-FA (mg/g of NDF) & 9.55 & 1.71 & 6.41 & 11.68 \\
Et-FA (mg/g of DM) & 1.81 & 0.37 & 1.11 & 2.29 \\
Et-FA (mg/g of NDF) & 5.00 & 1.01 & 3.53 & 6.73 \\
\hline
\end{tabular}

${ }^{1} \mathrm{KL}=$ Klason lignin; ivNDFD24 $=$ in vitro NDF digestibility at $24 \mathrm{~h}$; ivNDFD96 $=$ in vitro NDF digestibility at $96 \mathrm{~h}$; Es- $p$ CA $=$ esterified para-coumaric acid; Et- $p \mathrm{CA}=$ etherified para-coumaric acid; Es-FA = esterified ferulic acid; Et-FA = etherified ferulic acid.
Table 5. Chemical composition of the mature grasses $(n=6)$ analyzed in the in vitro portion of the study

\begin{tabular}{lrrcc}
\hline Item $^{1}$ & Mean & SD & Minimum & Maximum \\
\hline NDF (\% of DM) & 73.56 & 12.01 & 55.89 & 83.51 \\
ADF (\% of DM) & 47.82 & 9.91 & 33.81 & 56.21 \\
KL (\% of NDF) & 19.09 & 1.84 & 17.64 & 22.53 \\
ADL (\% of NDF) & 8.54 & 2.73 & 4.90 & 13.07 \\
ivNDFD24 (\% of NDF) & 38.71 & 13.81 & 22.31 & 62.61 \\
ivNDFD96 (\% of NDF) & 66.71 & 9.70 & 53.71 & 77.91 \\
Es- $p$ CA (mg/g of DM) & 3.10 & 0.35 & 2.79 & 3.60 \\
Es- $p$ CA (mg/g of NDF) & 3.25 & 6.22 & 2.30 & 19.49 \\
Et- $p$ CA (mg/g of DM) & 0.81 & 0.66 & 0.13 & 1.72 \\
Et- $p$ CA (mg/g of NDF) & 1.05 & 0.33 & 0.59 & 1.45 \\
Es-FA (mg/g of DM) & 2.11 & 1.19 & 1.57 & 2.62 \\
Es-FA (mg/g of NDF) & 3.05 & 1.53 & 1.88 & 6.09 \\
Et-FA (mg/g of DM) & 2.82 & 1.22 & 1.48 & 4.36 \\
Et-FA (mg/g of NDF) & 3.72 & 1.07 & 2.10 & 5.03
\end{tabular}

${ }^{1} \mathrm{KL}=$ Klason lignin; ivNDFD24 $=$ in vitro NDF digestibility at $24 \mathrm{~h}$; inNDFD96 $=$ in vitro NDF digestibility at $96 \mathrm{~h}$; Es- $p$ CA $=$ esterified para-coumaric acid; Et- $p \mathrm{CA}=$ etherified para-coumaric acid; Es-FA = esterified ferulic acid; Et-FA = etherified ferulic acid.

nin to arabinoxylan has been shown to reduce maize cell wall degradability (Grabber et al., 1998a,b). This relationship appeared to be counterintuitive for a higher digestibility plant; however, as previously indicated, Marita et al. (2003) obtained a greater amount of FA esterified to arabinoxylans in younger plants of bm3 cell walls compared with wild types. This strengthens the hypothesis that the $b m 3$ gene is not involved in FA biosynthesis and linkage. It might also suggest that the model used by Grabber et al. (1998a,b) did not involve any cells or linkages beyond the primary cell wall; thus, linkages in samples from this study, due to maturity, were more related to secondary cell wall and would not be expected to parallel the biomimetic system of Grabber et al. (1998a,b).

Table 6. Chemical composition of the immature grasses $(n=5)$ analyzed in the in vitro portion of the study

\begin{tabular}{lrrrr}
\hline Item $^{1}$ & Mean & SD & Minimum & Maximum \\
\hline NDF (\% of DM) & 43.91 & 3.02 & 39.41 & 46.81 \\
ADF (\% of DM) & 29.12 & 1.62 & 27.31 & 30.41 \\
KL (\% of NDF) & 20.96 & 3.71 & 16.34 & 24.40 \\
ADL (\% of NDF) & 6.80 & 1.03 & 5.66 & 8.46 \\
ivNDFD24 (\% of NDF) & 66.35 & 2.91 & 62.82 & 70.41 \\
ivNDFD96 (\% of NDF) & 78.91 & 2.30 & 76.12 & 81.91 \\
Es- $p$ CA (mg/g of DM) & 0.81 & 0.16 & 0.66 & 1.02 \\
Es- $p$ CA (mg/g of NDF) & 1.67 & 0.28 & 1.43 & 2.08 \\
Et- $p$ CA (mg/g of DM) & 0.33 & 0.23 & 0.03 & 0.57 \\
Et- $p$ CA (mg/g of NDF) & 0.32 & 0.20 & 0.05 & 0.56 \\
Es-FA (mg/g of DM) & 1.67 & 0.46 & 1.05 & 2.17 \\
Es-FA (mg/g of NDF) & 3.43 & 0.46 & 2.88 & 4.13 \\
Et-FA (mg/g of DM) & 0.70 & 0.31 & 0.30 & 1.16 \\
Et-FA (mg/g of NDF) & 1.55 & 0.50 & 0.77 & 2.10 \\
\hline
\end{tabular}

${ }^{1} \mathrm{KL}=$ Klason lignin; ivNDFD24 $=$ in vitro NDF digestibility at $24 \mathrm{~h}$; inNDFD96 $=$ in vitro NDF digestibility at $96 \mathrm{~h}$; Es- $p$ CA $=$ esterified para-coumaric acid; Et- $p$ CA = etherified para-coumaric acid; Es-FA = esterified ferulic acid; Et-FA = etherified ferulic acid. 
Table 7. Pearson correlation coefficients among the major variables investigated and among all forage groups ${ }^{1}$

\begin{tabular}{lcccccccc}
\hline & \multicolumn{7}{c}{ Variable } \\
\cline { 2 - 8 } Variable $^{2}$ & \multirow{2}{*}{ NDF } & ADF & ADL & KL & Es-FA & Et-FA & Es- $p$ CA & Et- $p$ CA \\
\hline NDF & & $0.97^{*}$ & $0.91^{*}$ & $0.92^{*}$ & $-0.45^{*}$ & $0.61^{*}$ & $-0.31^{*}$ & 0.23 \\
ADF & $-0.11^{*}$ & & $0.92^{*}$ & $0.93^{*}$ & $-0.50^{*}$ & $0.60^{*}$ & $-0.32^{*}$ & 0.32 \\
ADL & $-0.62^{* *}$ & $0.36^{*}$ & & $0.90^{*}$ & $-0.49^{*}$ & $0.63^{*}$ & $-0.20^{*}$ & $0.43^{*}$ \\
KL & 0.25 & $0.50^{*}$ & $0.56^{*}$ & & $-0.55^{*}$ & $0.46^{*}$ & $-0.33^{*}$ & 0.26 \\
Es-FA & $-0.74^{*}$ & -0.08 & $-0.59^{*}$ & $-0.54^{*}$ & & 0.01 & $0.77^{*}$ & -0.04 \\
Et-FA & -0.12 & -0.16 & $-0.21^{*}$ & $-0.44^{*}$ & $0.58^{*}$ & & 0.11 & $0.32^{*}$ \\
Es- $p$ CA & $-0.58^{* *}$ & -0.02 & $-0.23^{*}$ & $-0.33^{*}$ & $0.81^{*}$ & $0.52^{*}$ & & 0.19 \\
Et- $p$ CA & $-0.27^{*}$ & -0.16 & -0.03 & -0.17 & $0.39^{*}$ & 0.26 & $0.63^{*}$ & \\
\hline
\end{tabular}

${ }^{1}$ Correlations are expressed on a DM basis above the diagonal and on an NDF basis below the diagonal.

${ }^{2} \mathrm{KL}=$ Klason lignin; Es-FA = esterified ferulic acid; Et-FA = etherified ferulic acid; Es- $p \mathrm{CA}=$ esterified paracoumaric acid; Et- $p \mathrm{CA}=$ etherified para-coumaric acid.

*Significantly different from zero: $P<0.05$.

**Significantly different from zero: $P<0.01$.

Overall, the corn silages contained the highest values of Et- $p \mathrm{CA}$ among the forage samples analyzed and were in higher concentration than observed in other studies (Morrison et al., 1998). It should be recognized that estimates of Et- $p \mathrm{CA}$ are made by difference and are prone to error because the presence of Et- $p \mathrm{CA}$ might arise, in part, from difficulties in fully hydrolyzing $p \mathrm{CA}$ esters in lignin (Hartley and Morrison, 1991). Further, the observed higher values of Et- $p$ CA might reflect the use of the entire corn plant in our experiment, whereas most other experiments evaluated only the stem and leaf sections (Morrison et al., 1998). Due to the use of whole ensiled corn plants, it is possible that the higher amount of phenolic acids observed were from the corn grain, because both ferulic and coumaric acids are found in corn grain (Kandil et al., 2012; Luthria et al., 2014).

The similarity in Es-FA content and the difference in Et-FA $(P<0.05)$ between immature and mature grasses supports the concept that ferulate esters of arabinoxylans are deposited in the primary wall of grasses and ether cross-links to lignin form later (Ralph et al., 1998; Jung and Casler, 2006). A similar difference in Es- $p$ CA content between immature and mature grasses and between conventional and bmr corn silages supports previous observations that most $p \mathrm{CA}$ esters are on syringyl monolignol units (Ralph et al., 1994) and that only small quantities of $p \mathrm{CA}$ can be esterified to arabinoxylans in immature tissues (Morrison et al., 1998; Vailhé et al., 2000).

Correlation coefficients among fiber fractions and esterified or etherified $p \mathrm{CA}$ and FA content among all forages are in Table 7. Etherified FA was positively correlated with all fiber fractions on a DM basis $(P<$ $0.05)$, whereas it was negatively correlated $(P<0.05)$ with KL on an NDF basis. These correlations might result from some of the linkages being lost during the fiber analyses but still contributing to the individual fiber components. Overall, Es-FA and Es- $p$ CA were negatively correlated with all of the measured fiber fractions on both a DM basis and an NDF basis. This suggests that various processes leading to secondary cell wall development and cessation of cell growth are synchronized consistently in all forages (Casler and Jung, 2006), and lignin and phenolic acids might negatively affect NDF digestibility in a competitive manner (Casler and Jung, 1999) with specific cross-linking playing a larger role than lignin content per se (Grabber et al., 2009).

One of our objectives was to integrate knowledge about digestibility of different forage groups with their phenolic acid characteristics. The analysis was conducted among all forages to determine whether any specific phenolic acid or linkage affected rate and extent of fiber digestibility. Correlation coefficients among digestibility variables and lignin types and phenolic acids on an NDF and ADF basis are found in Table 8. The highest and most significant correlations were obtained when pooling all forages. However, NDF digestibility values and rate coefficients were not consistent among forages. Using the data from all analyzed forages and evaluating only ADL, we detected a negative correlation between $\mathrm{ADL}$ and rate of digestion with the ester and ether linked $\mathrm{FA}$ and $p \mathrm{CA}$. In these analyses, $\mathrm{ADL}$ always resulted in a negative correlation with $\mathrm{k}_{\mathrm{d}}$, 24-h NDFD, and 96-h NDFD; however, this was significant $(P<$ 0.05 ) only for mature and immature grasses and pooled forages (Table 8). When analyzed on the NDF residue of bmr corn silages, the correlations for digestibility with Es-FA, Et-FA, and Es- $p$ CA were positive and significant. This observation is not consistent with the data of Grabber et al. (2009), which demonstrated in a biomimetic model that ferulate cross-linking had the greatest negative influence on fiber digestibility. The 
Table 8. Pearson correlation coefficients among digestibility variables and lignin types and phenolic acids on an NDF and ADF basis ${ }^{1}$

\begin{tabular}{|c|c|c|c|c|c|c|c|c|c|c|}
\hline Forage $^{2}$ & \multicolumn{4}{|c|}{$(\mathrm{NDF} \%)$} & \multicolumn{2}{|c|}{$(\mathrm{ADF} \%)$} & \multicolumn{2}{|c|}{$(\mathrm{NDF} \%)$} & \multicolumn{2}{|c|}{$(\mathrm{ADF} \%)$} \\
\hline \multicolumn{11}{|c|}{ BMR corn silage } \\
\hline $24 \mathrm{hNDFD}$ & -0.07 & -0.10 & $0.78^{*}$ & $0.54^{*}$ & -0.26 & 0.28 & $0.79^{*}$ & -0.33 & $-0.88^{*}$ & $-0.67^{*}$ \\
\hline 96hNDFD & -0.14 & -0.21 & $0.60 *$ & $0.76^{*}$ & 0.00 & -0.09 & $0.52^{*}$ & -0.48 & $-0.78^{*}$ & $-0.54^{*}$ \\
\hline \multicolumn{11}{|c|}{ Conventional corn silage } \\
\hline \multicolumn{11}{|c|}{ Mature grasses } \\
\hline $\mathrm{k}_{\mathrm{d}}$ & $-0.72^{*}$ & -0.54 & $0.71^{*}$ & $-0.68^{*}$ & $-0.49^{*}$ & -0.36 & $-0.72^{*}$ & 0.51 & $-0.60^{*}$ & -0.49 \\
\hline $24 \mathrm{hNDFD}$ & $-0.90^{*}$ & -0.66 & $0.94^{*}$ & $-0.30^{*}$ & $-0.74^{*}$ & 0.00 & $-0.93^{*}$ & 0.14 & $-0.30^{*}$ & -0.72 \\
\hline 96hNDFD & $-0.90^{*}$ & -0.79 & $0.72^{*}$ & $-0.41^{*}$ & $-0.75^{*}$ & -0.14 & $-0.88^{*}$ & 0.17 & -0.64 & -0.58 \\
\hline \multicolumn{11}{|c|}{ Immature grasses } \\
\hline $\mathrm{k}_{\mathrm{d}}$ & $-0.63^{*}$ & 0.22 & -0.61 & $0.86^{*}$ & -0.41 & -0.24 & 0.24 & 0.06 & 0.16 & 0.21 \\
\hline 96hNDFD & $-0.73^{*}$ & $-0.34^{*}$ & $0.38^{*}$ & 0.12 & $-0.35^{*}$ & $-0.52^{*}$ & -0.07 & 0.09 & $-0.49^{*}$ & 0.16 \\
\hline
\end{tabular}

${ }^{1} \mathrm{KL}=$ Klason lignin; Es-FA = esterified ferulic acid; Et-FA = etherified ferulic acid; Es- $p$ CA = esterified para-coumaric acid; Et- $p$ CA $=$ etherified para-coumaric acid.

${ }^{2} \mathrm{k}_{\mathrm{d}}=$ rate of digestion, $\% / \mathrm{h} ; 24 \mathrm{hNDFD}=24-\mathrm{h}$ NDF digestibility; 96hNDFD $=96-\mathrm{h}$ NDF digestibility.

*Values differ significantly from zero $(P<0.05)$.

current data would suggest that within the bmr plant, the FA esters and ethers bonds are formed, producing measurable FA, but that a final polymerization step is not occurring, thus not negatively affected digestibility, and this might be related to differences between primary and secondary cell walls with respect to specific linkages. The bmr corn silages have higher levels of FA in NDF but this concentration is not a good indicator of digestibility. Further, Et-FA in NDF is not a good indicator of polysaccharide-lignin cross-linking in bmr corn silage similar to immature grasses, suggesting that the bmr gene maintains immature behavior, low level cross-linking and polymerization, in a mature plant.

Generally, the mature grasses and the conventional corn silages demonstrated similar behavior among linkages and measures of digestibility. The mature and immature grasses differed, especially for KL, Et-FA, and Et- $p \mathrm{CA}$, where the immature grasses demonstrated positive digestibility with KL and most of the etherified phenolic linkages and the opposite for the mature grasses. Further, when analyzed on an NDF basis, mature grasses demonstrated positive correlations between Es-FA and all digestibility measures, whereas the correlations became negative on an ADF basis. There was a strong positive correlation with Es- $p \mathrm{CA}$ and digestibility in bmr corn silages, and this relationship was only observed in bmr corn silages, demonstrating differences in how linkages are altered in the bmr plant. We also detected differences among the forage families between 24-h NDFD and Es-FA, where bmr corn silages and mature grasses demonstrated positive relationships with digestion but other forages demonstrated negative associations with phenolic acid content and digestibility. These observations are not consistent with the biomimetic model of cell wall digestibility and FA from Grabber et al. (2009). The differences might be related to the use of the whole plant, including grain and cob. Similar observations were made of forage digestibility and phenolic acid linkages when evaluated at $96 \mathrm{~h}$ of digestion. A positive relationship between Es- $p$ CA and 96-h digestibility in the NDF residues of bmr corn silages was observed. There was a positive relationship in 96-h NDFD on an NDF basis and in Es-FA for the grasses and the bmr corn silages. According to Grabber et al. (2004), correlative studies dealing with ferulates such as this are often hampered because ferulates recovered after alkaline or acid hydrolysis represent a small and variable proportion of the total ferulates deposited in cell walls. Our analysis of the fractions was designed to help clarify this recovery problem by providing more information on the location and respective differences in ferulates among fractions. The different recoveries of both $p \mathrm{CA}$ and $\mathrm{FA}$ in NDF among forage groups demonstrated how the amount of phenolic acids in whole-plant samples might bias these correlations (Jung and Shalita-Jones, 1990). The higher solubility of $p \mathrm{CA}$ in bmr corn silages is consistent with higher digestibility with less $p \mathrm{CA}$ incorporation and 
Table 9. Mean ( \pm SD) p-coumaric and ferulic acids recovered in NDF, ADF, and Klason lignin as percent of the total measured in the intact samples

\begin{tabular}{|c|c|c|c|c|c|c|}
\hline \multirow[b]{2}{*}{ Item } & \multicolumn{3}{|c|}{$p$-Coumaric acid } & \multicolumn{3}{|c|}{ Ferulic acid } \\
\hline & $\mathrm{NDF}$ & $\mathrm{ADF}$ & Klason lignin & $\mathrm{NDF}$ & $\mathrm{ADF}$ & Klason lignin \\
\hline Conventional corn silages & $75.04^{\mathrm{b}} \pm 12.82$ & $30.42^{\mathrm{a}} \pm 3.01$ & $9.37^{\mathrm{a}} \pm 2.38$ & $82.06 \pm 10.05$ & $5.05^{\mathrm{b}} \pm 1.69$ & $3.00 \pm 1.16$ \\
\hline Mature grasses & $88.57^{\mathrm{ab}} \pm 5.82$ & $24.05^{\mathrm{a}} \pm 9.27$ & $6.94^{\mathrm{a}} \pm 2.75$ & $92.31 \pm 6.14$ & $6.33^{\mathrm{a}} \pm 3.76$ & $3.48 \pm 1.66$ \\
\hline Immature grasses & $75.87^{\mathrm{ab}} \pm 12.08$ & $8.35^{\mathrm{b}} \pm 2.71$ & $7.91^{\mathrm{a}} \pm 3.18$ & $89.66 \pm 9.04$ & $2.89^{\mathrm{bc}} \pm 0.79$ & $3.19 \pm 1.16$ \\
\hline
\end{tabular}

${ }^{\mathrm{a}-\mathrm{c}}$ Values within columns with different superscript letters are significantly different $(P<0.05)$.

smaller $p$ CA-lignin complexes, similar to the data of Marita et al. (2003).

The amount of $p \mathrm{CA}$ and $\mathrm{FA}$ recovered in each of the fractions compared with intact sample amounts are given in Table 9 and expressed as a percent of the total phenolic acids recovered in the whole forage sample. Overall, use of ND solution to remove carbohydrate resulted in a loss of both $p \mathrm{CA}$ and $\mathrm{FA}$ from 3 and $25 \%$ among all samples, with no differences between ether and ester linkages. The loss of phenolic acids due to the ADF and KL procedures was larger $(P<0.05)$ for esterified than for etherified FA, presumably because the FA esterified to arabinose substitutions was solubilized during those procedures. Several studies have shown that a proportion of FA might act not only as a cross-linking agent between lignin and carbohydrates but also among carbohydrates to strengthen the cell wall (Eraso and Hartley, 1990; Bartolomé et al., 1997; Iiyama and Lam, 2001).

The multiple regression and stepwise selection procedures identified significant relationships among the rate and extent of digestion with phenolic acids and linkages for all forages, with $\mathrm{R}^{2}$ that varied between 0.56 and 0.99 (Table 10). The results demonstrated that for each forage or stage of maturity, the factors affecting rate and extent of fiber digestion are not the same and properties of linkages play an integral role in digestion behavior of plants. For example, in grasses, correlations of ADL and Et-FA were both significantly negative for rate and 96-h extent of digestion but were not identified as significant factors for bmr corn silage digestion. In fact, 96-h NDFD was positively related to Et-FA. These data indicate that the KL has the most negative effect on rate of digestion of bmr corn silage and 24-h extent of digestion, whereas conventional corn silages are most negatively affected by ADL and Es-FA (Table 10), consistent with the data of Grabber et al. (2009). Both Es-pCA and Et-FA measured in ADF had a negative effect on NDF digestibility. Boiling in acid detergent solution likely solubilized phenolic acids not involved in cell wall cross-linking, similar to data from Lowry et al. (1994). Whether these data support an overall genetic effect or a potential effect of the agronomic conditions from which our samples were generated is unknown.

\section{In Vivo Study}

The bmr mutation is associated with improved plant digestibility and this was observed in the current experiment. However, studies can be equivocal relative to

Table 10. The independent variables selected for each forage group and dependent variable by a multiple regression with stepwise selection within each forage group using the independent variable lignin type (ADL or Klason lignin, KL) and their difference (NDF basis) and phenolic acids with their specific linkages (NDF basis) examining the primary factors affecting rate and $24 \mathrm{~h}$ and $96 \mathrm{~h}$ NDFD

Forage group ${ }^{2}$

\begin{tabular}{|c|c|c|c|c|c|c|c|c|}
\hline & & & & & & & & \\
\hline$\frac{\text { Dependent variable }^{1}}{\mathrm{k}_{\mathrm{d}}}$ & \multicolumn{2}{|c|}{ Brown midrib corn } & \multicolumn{2}{|c|}{ Conventional corn } & \multicolumn{2}{|c|}{ Mature grasses } & \multicolumn{2}{|c|}{ Immature grasses } \\
\hline $\mathrm{R}^{2}$ & $\begin{array}{l}\mathrm{KL}: \\
\mathrm{Es}-p \mathrm{CA}:\end{array}$ & $\begin{array}{r}-0.45 \\
1.04 \\
0.84\end{array}$ & $\begin{array}{l}\text { ADL: } \\
\text { Es-FA: }\end{array}$ & $\begin{array}{r}-0.74 \\
-1.07 \\
0.79\end{array}$ & $\begin{array}{l}\text { ADL: } \\
\text { Et-FA: }\end{array}$ & $\begin{array}{r}-0.72 \\
-0.68 \\
0.97\end{array}$ & Et-FA: & 0.87 \\
\hline $24 \mathrm{~h}$ ivNDFD & \multirow{3}{*}{$\begin{array}{l}\mathrm{KL}: \\
\mathrm{Es}-p \mathrm{CA}:\end{array}$} & -0.62 & \multirow[t]{3}{*}{ Et- $p$ CA: } & \multirow[t]{2}{*}{-0.75} & ADL: & & \multirow{3}{*}{$\begin{array}{l}\text { ADL: } \\
\text { Es- } p \text { CA: }\end{array}$} & -1.12 \\
\hline & & 1.09 & & & Et-FA: & & & 0.36 \\
\hline $\mathrm{R}^{2}$ & & 0.92 & & 0.56 & & 0.98 & & 0.97 \\
\hline & Et-FA: & 0.70 & & & Et-FA: & -0.40 & ADL: & -0.59 \\
\hline & Es- $p$ CA: & 0.34 & & & & & Et-FA: & 0.48 \\
\hline $\mathrm{R}^{2}$ & & 0.84 & & & & 0.97 & & 0.99 \\
\hline
\end{tabular}

${ }^{1} \mathrm{k}_{\mathrm{d}}=$ rate of digestion, $\% / \mathrm{h}$; ivNDFD $=$ in vitro NDF digestibility. Significance level $=0.10$.

${ }^{2} \mathrm{Et}-\mathrm{FA}=$ etherified ferulic acid; Es-FA = esterified ferulic acid; Et- $p \mathrm{CA}=$ etherified $p$-coumaric acid; Es- $p$ CA = esterified $p$-coumaric acid. 
the increased digestibility of bmr varieties or the in vivo responses (Tine et al., 2001; Barrière et al., 2004). The nutritional characteristics of the corn silages used and the diet parameters along with the DMI and TTD of the 3 iso-NDF diets provided to the fistulated cows are shown in Tables 1 and 2, respectively. Of the 3 silages, only bmr corn silage resulted in a higher digestibility $(P<0.05)$. Average DMI $( \pm \mathrm{SD})$ of the cows were 26.53 $( \pm 1.36), 25.33( \pm 2.41)$, and $26.91( \pm 1.59) \mathrm{kg} / \mathrm{d}$ for the CLD, CHD, and BMR diets, respectively, and did not differ among each other $(P>0.05)$. As expected, TTD followed the observed in vitro NDFD values of the corn silages, with TTD values of 63,66 , and $70 \%$ for the CLD, CHD, and BMR TMR, respectively, and were different $(P<0.05)$. Analyses of phenolic acids in all ingredients of the TMR, feces, urine, and plasma allowed us to determine the total amount of FA and $p \mathrm{CA}$ (with respective linkages) ingested and excreted, using urine and feces excreted. We were not able to detect any phenolic acids in plasma, and urine contained a small amount of phenolic acids $(<0.50 \mathrm{~g}$ of total FA or $p$ CA per cow $)$ and did not differ among diets $(P=0.56$; data not shown).

The amount of ingested and excreted phenolic acids in the TMR and feces and the NDF and ADF fractions of the diets and feces are given in Table 11. The lower Es- $p$ CA concentration in the bmr diet compared with other 2 diets corresponded to the highest TTD for cows fed that treatment. Esterified hydroxycinnamic acids are partly digested in the ruminant digestive tract, as is apparent from the total acids ingested and excreted; however, the lower content of Es-FA in the bmr-based diet and feces corresponded to the highest TTD (Table 11). Consistent differences were found among all 3 diets between intake and excretion of the phenolic acids, with ranges between 10 and $42 \mathrm{~g}$ and 4 and $38 \mathrm{~g}$ for TMR and NDF samples, respectively. The amount of FA $(<0.50 \mathrm{~g}$ of total FA per cow $)$ in urine represented only a small portion of the phenolic acid ingested, and therefore a portion of it must be digested as indicated by Besle et al. (1995). Ferulic acid is more extensively degraded than $p \mathrm{CA}$ both in vivo (Giger, 1985) and in vitro, where it is metabolized at the same rate as hemicellulose (Jung, 1989).

For all diets, the difference in phenolic acid content between TMR and feces was near zero in the ADF residue samples (Tables 11 and 12). Both the TMR and the NDF residue samples of the diets demonstrated that Et-FA is not a good proxy for digestibility. However, this changed when evaluating the ADF residues; the forages with greater Et-FA values demonstrated lower digestibility (i.e., CLD). The acid detergent solution is potentially acting to remove those surface linkages easily cleaved by bacteria, while leaving the linkages that

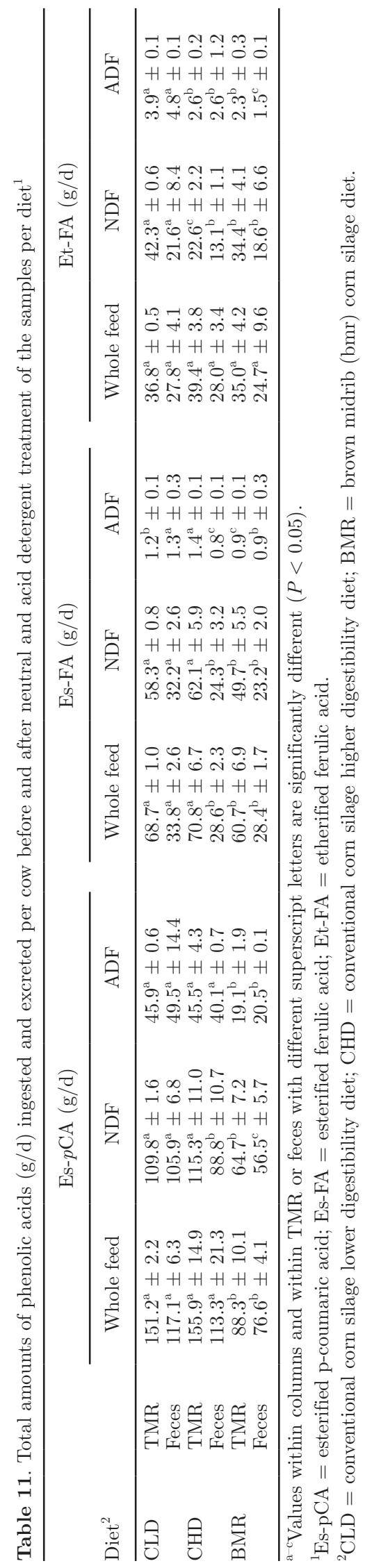


Table 12. The percent of phenolic acids that disappeared from ingestion to feces by phenolic acid in the whole feed and after neutral and acid detergent treatment of the samples per $\operatorname{diet}^{1}$

\begin{tabular}{|c|c|c|c|c|c|c|c|c|c|}
\hline $\operatorname{Diet}^{2}$ & \multicolumn{3}{|c|}{ Es- $p$ CA (\%) } & \multicolumn{3}{|c|}{ Es-FA $(\%)$} & \multicolumn{3}{|c|}{ Et-FA (\%) } \\
\hline CHD & 27 & 22 & 0 & 60 & 44 & 0 & 28 & 40 & 0 \\
\hline BMR & 13 & 15 & 0 & 53 & 54 & 0 & 31 & 47 & 0 \\
\hline
\end{tabular}

${ }^{1}$ Es-pCA = esterified p-coumaric acid; Es-FA = esterified ferulic acid; Et-FA = etherified ferulic acid.

${ }^{2} \mathrm{CLD}=$ conventional corn silage lower digestibility diet; $\mathrm{CHD}=$ conventional corn silage higher digestibility diet; BMR $=$ brown midrib $($ bmr $)$ corn silage diet.

cause a decrease in NDF digestibility. Previous data describing the phenolic acid content of ADF residues are not available and therefore comparisons with previous literature are not possible. Regressions of TTD on all the specific phenolic acids ingested and correlations between TTD and each linkage-specific phenolic acid were computed. Taboada et al. (2010) studied digestibility of silages in relation to their hydroxycinnamic acid content and lignin. In that study, in vivo DM digestibility ranged from 46 to $76 \%$ and all the phenolic fractions had a negative effect on digestibility. In this study, we detected negative but nonsignificant correlations between Es- $p$ CA (-0.44), Es-FA (-0.56), and Et-FA $(-0.36)$ in NDF and TTD, and this was also observed by Taboada et al. (2010). They found no correlation between the ferulic acid fractions (on an NDF basis) and in vivo DM and OM digestibility. Only ferulic ethers, which may act as cross-linkages between hemicellulose and lignin, seemed to partially explain differences in in vivo digestibility, in agreement with previous studies (Jung and Buxton, 1994; Argillier et al., 1996). In this study, the analysis of phenolic acids in the ADF residues provided some explanation for the in vivo differences in TTD for all fractions, especially for FA content. The difference in digestibility follows the observation that compared with $p \mathrm{CA}, \mathrm{FA}$ is released more quickly from the cell wall during digestion. In fact, FA was found to be among the most rapidly and extensively removed constituents from plant cell walls (Faulds and Williamson, 1999). The acid detergent treatment might have a similar effect in removing those FA that are removed more quickly during digestion.

\section{CONCLUSIONS}

In this study, the relationship among phenolic acids and in vitro digestibility and extent of digestion was investigated in whole plants and various chemical and digested fractions. Lignin type and linkages of phenolic acids explained a reasonable portion of the variation in NDFD, but not uniformly among varieties and stage of maturity, indicating that use of the same factors to explain digestibility in all forages across all agronomic conditions will likely lead to erroneous characterizations. Ferulic acid and $p$-coumaric acid ester and ether linkages among lignin-carbohydrate complexes appear to be distributed in the different chemical fractions of the plant but not uniformly across forage families; therefore, consistency is needed when reporting their respective amounts in plants. Overall, these data demonstrate that the detergent system and the chemical composition of the plant are not significant indicators of the rate and extent of digestibility, and that the linkages among fractions explain a larger portion of the digestion behavior consistent with previous data.

\section{ACKNOWLEDGMENTS}

This work was partially supported by the USDA under Hatch Grant NYC-127410 entitled Indigestible Neutral Detergent Fiber (iNDF) in Forage Evaluation.

\section{REFERENCES}

Akin, D. E., and R. Benner. 1988. Degradation of polysaccharides and lignin by ruminal bacteria and fungi. Appl. Environ. Microbiol. 54:1117-1125.

Akin, D. E., and A. Chesson. 1989. Lignification as the major factor limiting forage feeding value especially in warm conditions. Pages 1753-1760 in Proc. XVI Int. Grassl. Congr., Nice, France. Assoc. Francaise pour la Production Fourragere, Nice, France.

Argillier, O., Y. Barrière, M. Lila, F. Jeanneteau, K. Gélinet, and V. Menanteau. 1996. Genotypic variation in phenolic components of cell walls in relation to the digestibility of maize stalks. Agronomie 16:123-130. https://doi.org/10.1051/agro:19960206.

Barrière, Y., J. Ralph, V. Méchin, S. Guillaumie, J. H. Grabber, O Argillier, B. Chabbert, and C. Lapierre. 2004. Genetic and molecular basis of grass cell wall biosynthesis and degradability. II. Lessons from brown-midrib mutants. C. R. Biol. 327:847-860. https://doi.org/10.1016/j.crvi.2004.05.010.

Bartolomé, B., C. B. Faulds, P. A. Kroon, K. Waldron, H. J. Gilbert, G. Hazlewood, and G. Williamson. 1997. An Aspergillus niger esterase (ferulic acid esterase III) and a recombinant Pseudomonas fluorescens ssp. cellulosa esterase (XylD) from barley and wheat cell walls. Appl. Environ. Microbiol. 63:208-212.

Besle, J. M., J. P. Jouany, and A. Cornu. 1995. Transformations of structural phenylpropanoids during cell wall digestion. FEMS Microbiol. Rev. 16:33-52. https://doi.org/10.1111/j.1574-6976.1995 .tb00154.x. 
Casler, M. D., and H. J. G. Jung. 1999. Selection and evaluation of smooth bromegrass clones with divergent lignin or etherified ferulic acid concentration. Crop Sci. 39:1866-1873. https://doi.org/10 .2135 /cropsci1999.3961866x.

Casler, M. D., and H. J. G. Jung. 2006. Relationships of fibre, lignin, and phenolics to in vitro fibre digestibility in three perennial grasses. Anim. Feed Sci. Technol. 125:151-161. https://doi.org/10 .1016/j.anifeedsci.2005.05.015.

Chabannes, M., A. Barakate, C. Lapierre, J. M. Marita, J. Ralph, M. Pean, S. Danoun, C. Halpin, J. Grima-Pettenati, and A. M. Boudet. 2001. Strong decrease in lignin content without significant alteration of plant development is induced by simultaneous downregulation of cinnamoyl CoA reductase (CCR) and cinnamyl alcohol dehydrogenase (CAD) in tobacco plants. Plant J. 28:257-270. https://doi.org/10.1046/j.1365-313X.2001.01140.x.

Chase, L. E. 2010. Milk production and feed efficiency in dairy cows fed corn silage hybrids varying in fiber digestibility. J. Dairy Sci. 93(E-Suppl. 1):755. (Abstr.)

Chen, X. B., G. Grubic, E. R. Ørskov, and P. Osuji. 1992. Effect of feeding frequency on diurnal variation in plasma and urinary purine derivatives in steers. Anim. Prod. 55:185-191. https://doi .org/10.1017/S0003356100037442.

Cherney, J. H., K. S. Anliker, K. A. Albrecht, and K. V. Wood. 1989 Soluble phenolic monomers in forage crops. J. Agric. Food Chem. 37:345-350. https://doi.org/10.1021/jf00086a016.

Cherney, J. H., D. J. R. Cherney, D. E. Akin, and J. D. Axtell. 1991. Potential of brown-midrib, low-lignin mutants for improving forage quality. Adv. Agron. 46:157-195. https://doi.org/10.1016/S0065 $-2113(08) 60580-5$

Chesson, A. 1993. Mechanistic models of forage cell wall degradation. Pages 347-376 in Forage Cell Wall Structure and Digestibility. H. G. Jung, D. R. Buxton, R. D. Hatfield and J. Ralph, ed. American Society of Agronomy, Crop Science Society of America, Soil Science Society of America, Madison, WI.

Coors, J. G., and J. G. Lauer. 2001. Silage corns. Pages 347-392 in Specialty Corns. 2nd ed. A. R. Hallauer, ed. CRC Press, Boca Raton, FL.

Eraso, F., and R. D. Hartley. 1990. Monomeric and dimeric phenolic constituents of plant cell walls - possible factors influencing wall biodegradability. J. Sci. Food Agric. 51:163-170. https://doi.org/ $10.1002 /$ jsfa.2740510203.

Faulds, C. B., and G. Williamson. 1999. The role of hydroxycinnamates in the plant cell wall. J. Sci. Food Agric. 79:393-395. https:// doi.org/10.1002/(SICI)1097-0010(19990301)79:3<393::AIDJSFA261>3.0.CO;2-H.

Giger, S. 1985. Revue sur les methodes de dosage de la lig-r. Revue sur les methodes de dosage de la lignine utilisées en alimentation animale. Ann. Zootech. 34:85-122.

Goering, H. K., and P. J. Van Soest. 1970. Forage fiber analysis (Apparatus, Reagents, Procedures and some Application). Agric. Handbook 379. Agricultural Research Service, USDA, Washington, DC.

Grabber, J. H. 2005. How do lignin composition, structure, and crosslinking affect degradability? A review of cell wall model studies. Crop Sci. 45:820-831. https://doi.org/10.2135/cropsci2004.0191.

Grabber, J. H., R. D. Hatfield, and J. Ralph. 1998a. Diferulate crosslinks impede the enzymatic degradation of non-lignified maize walls. J. Sci. Food Agric. 77:193-200. https://doi.org/10.1002/ (SICI) 1097-0010(199806)77:2<193::AID-JSFA25>3.0.CO;2-A.

Grabber, J. H., D. R. Mertens, H. Kim, C. Funk, F. Lua, and J. Ralph. 2009. Cell wall fermentation kinetics are impacted more by lignin content and ferulate cross-linking than by lignin composition. J. Sci. Food Agric. 89:122-129. https://doi.org/10.1002/jsfa.3418.

Grabber, J. H., J. Ralph, and R. D. Hatfield. 1998b. Ferulate crosslinks limit the enzymatic degradation of synthetically lignified primary walls of maize. J. Agric. Food Chem. 46:2609-2614. https:// doi.org/10.1021/jf9800099

Grabber, J. H., J. Ralph, C. Lapierre, and Y. Barriere. 2004. Genetic and molecular basis of grass cell-wall degradability. I. Lignin-cell wall matrix interactions. C. R. Biol. 327:455-465. https://doi.org/ 10.1016/j.crvi.2004.02.009
Hartley, R. D., and W. H. Morrison III.. 1991. Monomeric and dimeric phenolic acids released from cell walls of grasses by sequential treatment with sodium hydroxide. J. Sci. Food Agric. 55:365-375. https://doi.org/10.1002/jsfa.2740550305.

Hatfield, R. D., and R. S. Fukushima. 2005. Can lignin be accurately measured? Crop Sci. 45:832-839. https://doi.org/10.2135/ cropsci2004.0238.

Hatfield, R. D., J. Ralph, and J. H. Grabber. 1999. Cell wall cross-linking by ferulates and diferulates in grasses. J. Sci. Food Agric. 79:403-407. https://doi.org/10.1002/(SICI)1097 -0010(19990301)79:3<403::AID-JSFA263>3.0.CO;2-0.

Hu, Y., W. C. Li, Y. Q. Xu, G. J. Li, Y. Liao, and F. L. Fu. 2009. Differential expression of candidate genes for lignin biosynthesis under drought stress in maize leaves. J. Appl. Genet. 50:213-223. https://doi.org/10.1007/BF03195675.

Iiyama, K., and T. B. T. Lam. 2001. Structural characteristics of cell walls of forage grasses - Their nutritional evaluation for ruminants-Review. Asian-australas. J. Anim. Sci. 14:862-879. https://doi.org/10.5713/ajas.2001.862.

Iiyama, K. T. B. T. Lam, and B. A. Stone. 1990. Phenolic acid bridges between polysaccharides and lignin in wheat internodes. Phytochemistry 29:733-737. https://doi.org/10.1016/0031 -9422(90)80009-6.

Jung, H. G. 1989. Forage lignins and their effects on fiber digestibility. Agron. J. 81:33-35. https://doi.org/10.2134/agronj1989 $.00021962008100010006 x$.

Jung, H. G., and M. D. Casler. 1990. Lignin concentration and composition of divergent smooth bromegrass genotypes. Crop Sci. 30:980-985. https://doi.org/10.2135/cropsci1990 .0011183 X003000050004x.

Jung, H. G., and M. D. Casler. 1991. Relationship of lignin and esterified phenolics to fermentation of smooth bromegrass fibre. Anim. Feed Sci. Technol. 32:63-68. https://doi.org/10.1016/0377 -8401(91)90010-P.

Jung, H. G., and M. D. Casler. 2006. Maize stem tissues: Cell wall concentration and composition during development. Crop Sci. 46:1793-1800. https://doi.org/10.2135/cropsci2005.02-0085.

Jung, H. G., and D. A. Deetz. 1993. Cell wall lignification and degradability. Pages 315-346 in Forage Cell Wall Structure and Digestibility. H. G. Jung, D. R. Buxton, R. D. Hatfield, and J. Ralph, ed. American Society of Agronomy, Madison, WI.

Jung, H. G., D. R. Mertens, and D. R. Buxton. 1998. Forage quality variation among maize inbreds: In vitro fiber digestion kinetics and prediction with NIRS. Crop Sci. 38:205-210. https://doi.org/ 10.2135/cropsci1994.0011183X003400060046x.

Jung, H. G., and S. C. Shalita-Jones. 1990. Variation in the extractability of esterified p-coumaric and ferulic acids from forage cell walls. J. Agric. Food Chem. 38:397-402. https://doi.org/10.1021/ jf00092a012.

Jung, H. J. G., and D. R. Buxton. 1994. Forage quality variation among maize inbreds: Relationships of cell-wall composition and in vitro degradability for stem internodes. J. Sci. Food Agric. 66:313322. https://doi.org/10.1002/jsfa.2740660308.

Jung, H. J. G., G. C. Fahey, and N. R. Merchen. 1983. Effects of ruminant digestion and metabolism on phenolic monomers of forages. Br. J. Nutr. 50:637-651.

Jung, H. J. G., J. Ralph, and R. D. Hatfield. 1991. Degradability of phenolic acid-hemicellulose esters: A model system. J. Sci. Food Agric. 56:469-478. https://doi.org/10.1002/jsfa.2740560407.

Kandil, A., J. Li, T. Vasanthan, and D. C. Bressler. 2012. Phenolic acids in some cereal grains and their inhibitory effect on starch liquefaction and saccharification. J. Agric. Food Chem. 60:8444-8449. https://doi.org/10.1021/jf3000482.

Lam, T. B. T., K. Iiyama, and B. A. Stone. 1992a. Changes in phenolic acids from internode walls of wheat and phalaris during maturation. Phytochemistry 31:2655-2658. https://doi.org/10.1002/jsfa .2740640110 .

Lam, T. B. T., K. Iiyama, and B. A. Stone. 1992b. Cinnamic acid bridges between cell wall polymers in wheat and phalaris internodes. Phytochemistry 31:1179-1183. https://doi.org/10.1016/ 0031-9422(92)80256-E. 
Lam, T. B. T., K. Iiyama, and B. A. Stone. 2003. Hot alkali-labile linkages in the walls of the forage grass phalaris aquatica and lolium perenne and their relation to in vitro wall digestibility. Phytochemistry 64:603-607.

Lam, T. B. T., K. Kadoya, and K. Iiyama. 2001. Bonding of hydroxycinnamic acids to lignin: Ferulic and p-coumaric acids are predominantly linked at the benzyl position of lignin, not the [beta]position, in grass cell walls. Phytochemistry 57:987-992. https:// doi.org/10.1016/S0031-9422(01)00052-8.

Lowry, J. D., L. L. Conlan, A. C. Schlink, and C. S. McSweeney. 1994. Acid detergent dispersible lignin in tropical grasses. J. Sci. Food Agric. 65:41-49. https://doi.org/10.1002/jsfa.2740650108.

Luthria, D. L., A. A. Memon, and K. Liu. 2014. Changes in phenolic acid content during dry-grind processing of corn into ethanol and DDGS. J. Sci. Food Agric. 94:1723-1728. https://doi.org/10.1002/ jsfa.6481.

Marita, J. M., W. Vermerris, J. Ralph, and R. D. Hatfield. 2003. Variations in the cell wall composition of maize brown midrib mutants. J. Agric. Food Chem. 51:1313-1321. https://doi.org/10 $.1021 /$ jf0260592.

Mertens, D. R. 2002. Gravimetric determination of amylase-treated neutral detergent fiber in feeds with refluxing in beakers or crucibles: Collaborative study. J. AOAC Int. 85:1217-1240.

Morrison, T. A., H. G. Jung, D. R. Buxton, and R. D. Hatfield. 1998. Cell-wall composition of maize internodes of varying maturity. Crop Sci. 38:455-460. https://doi.org/10.2135/cropsci1998 .0011183X003800020031x.

Neter, J., M. H. Kutner, C. J. Nachtsheim, and W. Wasserman. 1996. Applied Linear Statistical Methods. Irwin, Chicago, IL.

Neter, J., W. Wasserman, and M. H. Kutner. 1985. Applied Linear Statistical Models. Richard D. Irwin Inc., Homewood, IL.

Oba, M., and M. S. Allen. 2003. Effects of corn grain conservation method on feeding behavior and productivity of lactating dairy cows at two dietary starch concentrations. J. Dairy Sci. 86:174183. https://doi.org/10.3168/jds.S0022-0302(03)73598-X.

Raffrenato, E., and M. E. Van Amburgh. 2010. Development of a mathematical model to predict sizes and rates of digestion of a fast and slow degrading pool and the indigestible NDF fraction. Pages 52-65 in Proc. Cornell Nutr. Conf Feed Manufacturers. Department of Animal Science, Cornell Univ., Ithaca, NY. http://hdl .handle.net/1813/37008.

Raffrenato, E., and M. E. Van Amburgh. 2011. Technical Note: Improved methodology for analyses of acid detergent fiber and acid detergent lignin. J. Dairy Sci. 94:3613-3617. https://doi.org/10 .3168/jds.2010-3701.

Ralph, J., R. D. Hatfield, J. H. Grabber, H. G. Jung, S. Quideau, and R. F. Helm. 1998. Cell wall cross-linking in grasses by ferulates and diferulates. Pages 209-236 in Lignin and Lignan Biosynthesis. N. G. Lewis and S. Sarkanen, ed. American Chemical Society, Washington, DC. 10.1021/bk-1998-0697.ch016.

Ralph, J., R. D. Hatfield, S. Quideau, R. F. Helm, J. H. Grabber, and H. J. G. Jung. 1994. Pathway of $p$-coumaric acid incorporation into maize lignin as revealed by NMR. J. Am. Chem. Soc. 116:9448-9456. https://doi.org/10.1021/ja00100a006.

Robertson, J. B., and P. J. Van Soest. 1981. The detergent system of analysis and its application to human foods. Pages 123-154 in The Analysis of Dietary Fiber in Food. W. P. T. James and O. Theander, ed. Marcel Dekker, New York, NY.

Rodrigues, M. A. M., C. M. Guedes, J. W. Cone, A. H. van Gelder, L. M. M. Ferreira, and C. A. Sequeira. 2007. Effects of phenolic acid structures on meadow hay digestibility. Anim. Feed Sci. Technol. 136:297-311. https://doi.org/10.1016/j.anifeedsci.2006.09.009.

Taboada, A., E. Novo-Uzal, G. Flores, M. Loureda, A. Ros Barceló, A. Masa, and F. Pomar. 2010. Digestibility of silages in relation to their hydroxycinnamic acid content and lignin composition. J. Sci. Food Agric. 90:1155-1162. https://doi.org/10.1002/jsfa.3933.

Theander, O., P. Aman, E. Westerlund, R. Andersson, and D. Pettersson. 1995. Total dietary fiber determined as neutral sugar residues, uronic acid residues, and klason lignin (the Uppsala method): Collaborative study. J. AOAC Int. 78:1030-1044.

Tine, M. A., K. R. McLeod, R. A. Erdman, and R. L. Baldwin. 2001. Effects of brown midrib corn silage on the energy balance of dairy cattle. J. Dairy Sci. 84:885-895. https://doi.org/10.3168/jds.S0022 -0302(01)74546-8.

Vailhé, M. A. B., G. J. Provan, L. Scobbie, A. Chesson, M. P. Maillot, A. Cornu, and J. M. Besle. 2000. Effect of phenolic structures on the degradability of cell walls isolated from newly extended apical internode of tall fescue (Festuca arundinacea Schreb.). J. Agric. Food Chem. 48:618-623. https://doi.org/10.1021/jf9906329.

Van Amburgh, M. E., R. Grant, K. Cotanch, A. Zontini, D. Ross, and A. Foskolos. 2015. NDF-Making something old, new again. Herd Health and Nutrition Conference, Syracuse, NY. Cornell University, Ithaca, NY. http://hdl.handle.net/1813/39211.

Van Keulen, J. V., and B. A. Young. 1977. Evaluation of acid insoluble ash as a natural marker in ruminant digestibility studies. J. Anim. Sci. 44:282-287. https://doi.org/10.2527/jas1977.442282x.

Van Soest, P. J. 1963. Use of detergents in the analysis of fibrous feeds. II. A rapid method for the determination of fiber and lignin. J. Assoc. Off. Agric. Chem. 46:829-835.

Zhao, Z., Y. Egashira, and H. Sanada. 2003. Ferulic acid sugar esters are recovered in rat plasma and urine mainly as the sulfoglucuronide of ferulic acid. J. Nutr. 133:1355-1361. 